\title{
THE ANALYSIS OF CHOICE INFLUENCE IN FATIGUE FAILURE CRITERIA ON INTEGRITY ASSESSMENT OF WAGON STRUCTURE
}

\author{
Vladimir Milovanović, Miroslav Živković, Gordana Jovičić, Dražan Kozak
}

Original scientific paper

This paper presents the S-N approach to fatigue failure analysis of welded joints that integrates well with finite element modelling. Goodman's criterion and fatigue criterion based on the equivalent stress range were used for the analysis of the fatigue failure. Goodman's criterion and fatigue criterion based on the equivalent stress range, for determining fatigue safety factor are implemented in the software package for finite element analysis PAK. Numerical calculation of fatigue safety factor was determined to assess the integrity of wagon structure parts according to the most commonly used European standards for wagon analysis. According to failure safety factors obtained by Goodman's criterion and fatigue criterion based on the equivalent stress range it should be noticed that both methods give good results. Both criteria give us adequate identification causes of cracking on the underframe of wagon for containers transportation. The obtained results and their well matching prove reliability of both fatigue failure criteria and that they can be used for integrity assessment of wagon structure parts.

Keywords: fatigue failure; failure safety factor; FEM; Goodman's criterion

Analiza utjecaja izbora kriterija otkaza uslijed zamora na procjenu integriteta vagonske konstrukcije

Izvorni znanstveni članak

U radu je predstavljen S-N pristup analize otkaza zavarenih spojeva uslijed zamora povezan s metodom konačnih elemenata. Pri analizi otkaza uslijed zamora kriteriji rabljeni za analizu su Goodmanov kriterij i kriterij utemeljen na opsegu efektivnog naprezanja. Goodmanov kriterij i kriterij utemeljen na opsegu efektivnog naprezanja, za određivanje stupnja sigurnosti do otkaza uslijed zamora, implementirani su u softverski paket PAK. Numeričkim proračunima određen je stupanj sigurnosti do otkaza u cilju procjene integriteta dijelova vagonske konstrukcije u skladu s najčešće rabljenim standardima za proračun i analizu vagonskih konstrukcija. Na osnovu izračunatih stupnjeva sigurnosti do otkaza dobivenih Goodmanovim kriterija i kriterija utemeljenih na opsegu efektivnog naprezanja pokazano je da obje metode daju dobre rezultate. Oba kriterija identificiraju prave uzroke pojave pukotina na donjem postolju vagona za prijevoz kontejnera. Dobiveni rezultati i njihovo međusobno dobro poklapanje oba kriterija za određivanje otkaza uslijed zamora nam daju za pravo da se oba kriterija mogu ravnopravno koristiti za procjenu integriteta vagonskih konstrukcija.

Ključne riječi: Goodmanov kriterij; MKE ;otkaz uslijed zamora; stupanj sigurnosti do otkaza

\section{Introduction}

Carrying parts of wagon structure loaded with periodic stresses that oscillate between some limits are subjected to stresses called repeated, alternating, or fluctuating stresses. Often the wagon structure parts fail under the action of repeated or fluctuating stresses. The most common cause of these failures is that the stresses have been repeated a very large number of times. Hence, the failure is called a fatigue failure. A fatigue failure begins with a small crack [1]. Once the crack is initiated, the stress concentration effect becomes greater and the crack progresses more rapidly. As the stressed area decreases in size, the stress increases in magnitude until the remaining area finally fails suddenly. A fatigue failure is characterized by two distinct regions. The first one is due to the progressive development of the crack, whereas the second one is due to the sudden fracture.

This paper presents the analysis of the load on the bottom part of the wagon underframe structure and fatigue failure analysis of the most critical zones based on S-N approach [2]. Goodman's criterion and fatigue criterion based on the equivalent stress for analysis of the fatigue failure phenomenon range were used [3]. According to calculation of fatigue safety factor integrity assessment of wagon structure parts was determined.

\section{Fatigue failure criteria - theoretical basis}

The initial analysis of the fatigue life is performed using the S-N approach, assuming that there was no occurrence of initial flow and the known fatigue endurance limit $S_{\mathrm{e}}$.

\subsection{Fatigue endurance limit}

Numerous tests have established that the ferrous materials have endurance limit defined as the highest level of alternating stress that can be withstood indefinitely without failure. The symbol for fatigue endurance limit is $S_{\mathrm{e}}^{\prime}$. The fatigue endurance limit can be related to the tensile strength through the following equation [4]

$S_{\mathrm{e}}^{\prime}=\left\{\begin{array}{ll}0,504 S_{\mathrm{ut}} & S_{\mathrm{ut}} \leq 1400 \mathrm{MPa} \\ 700 \mathrm{MPa} & S_{\mathrm{ut}}>1400 \mathrm{MPa}\end{array}\right.$,

where $S_{\mathrm{ut}}$ is the minimum tensile strength. The prime mark on $S_{\mathrm{e}}^{\prime}$ refers to the fatigue endurance limit of the test specimen itself, whereas the symbol $S_{\mathrm{e}}$ represents the fatigue endurance limit of a structure part subjected to any kind of loading.

The fatigue endurance limit is affected by some factors such as

$S_{\mathrm{e}}=S_{\mathrm{e}}^{\prime} k_{\mathrm{a}} k_{\mathrm{b}} k_{\mathrm{c}} k_{\mathrm{d}} k_{\mathrm{e}}$

where $k_{\mathrm{a}}$ is the surface factor, $k_{\mathrm{b}}$ is the size factor (gradient factor), $k_{\mathrm{c}}$ is the load factor, $k_{\mathrm{d}}$ is the temperature factor and $k_{\mathrm{e}}$ is the factor which takes into account all other influences. 


\subsection{The definition and description of fatigue loads}

Figure 1 shows cyclic tension/tension loading as the sinus function shape in the idealized form.

For the fatigue analysis of wagon structures according to TSI standard, Annex CC [5], fatigue load used in design is in the range of $\pm 30 \%$ of vertical static load. Based on design of fatigue load, cyclic values of the maximum stress $\sigma_{\max }$ and minimum stress $\sigma_{\min }$ can be expressed as sum of midrange or the mean stress $\sigma_{\mathrm{m}}$ and amplitude or the alternating stress $\sigma_{\mathrm{a}}$.

$$
\begin{gathered}
\sigma_{\max }=\sigma_{\mathrm{m}}+\sigma_{\mathrm{a}}=(1+0,3) \sigma_{\mathrm{m}}=1,3 \sigma_{\mathrm{m}} \Rightarrow \sigma_{\mathrm{m}}=\frac{\sigma_{\max }}{1,3} \\
\sigma_{\min }=\sigma_{\mathrm{m}}-\sigma_{\mathrm{a}}=(1-0,3) \sigma_{\mathrm{m}}=0,7 \sigma_{\mathrm{m}} \Rightarrow \sigma_{\mathrm{m}}=\frac{\sigma_{\min }}{0,7} .
\end{gathered}
$$

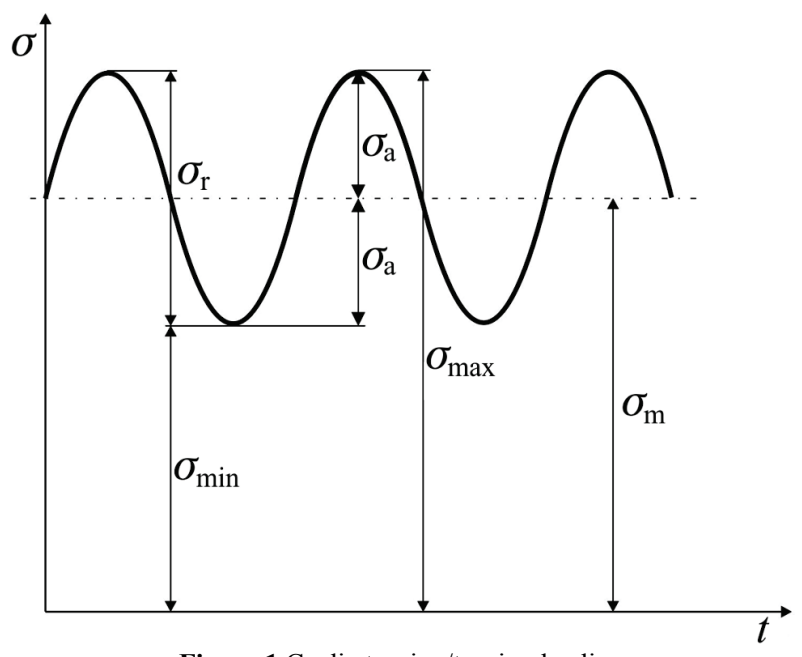

Figure 1 Cyclic tension/tension loading

Mean stress $\sigma_{\mathrm{m}}$ is half the sum of the maximum and minimum stress values

$\sigma_{\mathrm{m}}=\frac{\sigma_{\min }+\sigma_{\max }}{2}$

Stress amplitude $\sigma_{\mathrm{a}}$. is half the value of stress range $\sigma_{\mathrm{r}}$

$\sigma_{\mathrm{a}}=\frac{\sigma_{\mathrm{r}}}{2}=\frac{\sigma_{\max }-\sigma_{\min }}{2}$.

According to fatigue load shown in Fig. 1 and Eqs. (3), (4) and (6) the value of the maximum stress based on static analysis can be calculated:

$\sigma_{\max }=2,1667 \sigma_{\mathrm{r}}$

The stress ratios are used to describe mean stress under cyclic tension/tension loading.

$R=\frac{\sigma_{\min }}{\sigma_{\max }}=\frac{1-A}{1+A}$ and $A=\frac{\sigma_{\mathrm{a}}}{\sigma_{\mathrm{m}}} \frac{1-R}{1+R}$

\subsection{Criteria of failure}

Various techniques are used to plot the fatigue failure test results of a part subjected to fluctuating stress. Numerical values of the calculated maximum principal stress on the structures, for the two types of loads, are one load cycle used to calculate the failure safety factor, using S-N analysis. For assessment of failure safety factor, with adopted boundary conditions of cyclic loading structures, it is necessary to define the principal stresses in each integration point of finite element and the values of alternating stress and mean stress $[6,7]$.

In order to determine the influence and relationship between mean stress and stress amplitude many empirical formulas are developed. Those formulas define different curves to connect the fully reversed fatigue endurance limit $S_{\mathrm{e}}\left(\sigma_{\mathrm{m}}=0, R=-1\right)$, on the axis of alternating stress, with yield strength $S_{\mathrm{y}}$ (Goodman line); or ultimate tensile strength $S_{\mathrm{ut}}$ (Gerber parabola); or the true fracture strength $\sigma_{\mathrm{f}}$ (Morrow line), on the axis of mean stress.

The reciprocal value of the failure safety factor is calculated using the modified Goodman criteria of failure $[8,9]$ :

$\frac{\sigma_{\mathrm{a}}}{S_{\mathrm{e}}}+\frac{\sigma_{\mathrm{m}}}{S_{\mathrm{u}}}=\frac{1}{F S F_{\mathrm{GD}}}$,

similarly, the modified Goodman relation is

$\frac{S_{\mathrm{a}}}{S_{\mathrm{e}}}+\frac{S_{\mathrm{m}}}{S_{\mathrm{u}}}=1$

Meaning of these equations is illustrated in Fig. 2, using the modified Goodman theory as an example. The safe-stress line through $\mathrm{A}$ is constructed parallel to the modified Goodman line. The safe-stress line is the locus of all sets of $\sigma_{\mathrm{a}}-\sigma_{\mathrm{m}}$ stresses having a failure safety factor $F S F_{\mathrm{GD}}$, that is $S_{\mathrm{m}}=F S F_{\mathrm{GD}} \sigma_{\mathrm{m}}$ and $S_{\mathrm{a}}=F S F_{\mathrm{GD}} \sigma_{\mathrm{a}}$.

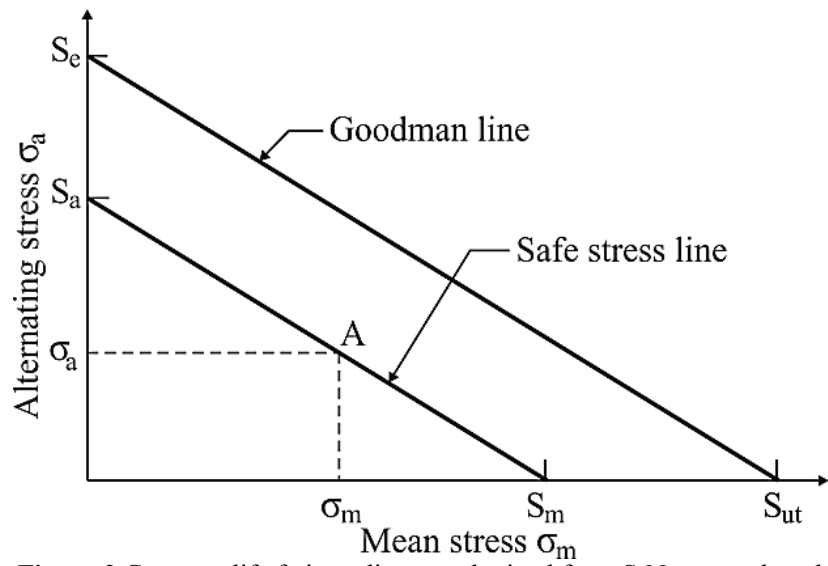

Figure 2 Constant-life fatigue diagram obtained from S-N approach and Goodman's criteria of failure

\section{Integrity assessment of wagon structure parts - example}

According to described theoretical basis, integrity assessment of wagon structure parts was determined according to calculation of fatigue safety factor. 
Goodman's criterion and fatigue criterion based on the equivalent stress range for determining fatigue safety factor are implemented in the software package PAK [10].

The wagon is designed for the transportation of containers and Swap Bodies (SBs) within block trains. The wagon is produced by the reconstruction of Gas type wagon. The underframe of Gas wagon is adapted for the containers transportation. The existing underframe is reconstructed, strengthened and enhanced to completely fulfil the request of TSI standard [5]. The bottom side of underframe is made of steel plates and rolled steel profiles, as a welded construction.

Eighty percent of all wagons, which were used in transport, have failure or initial cracks (Fig. 3). According to this fact, it was necessary to determine the reason for the appearance of the cracks according to calculated fatigue safety factor. The observed cracks appear on the welded joints or near the welded joints [11].
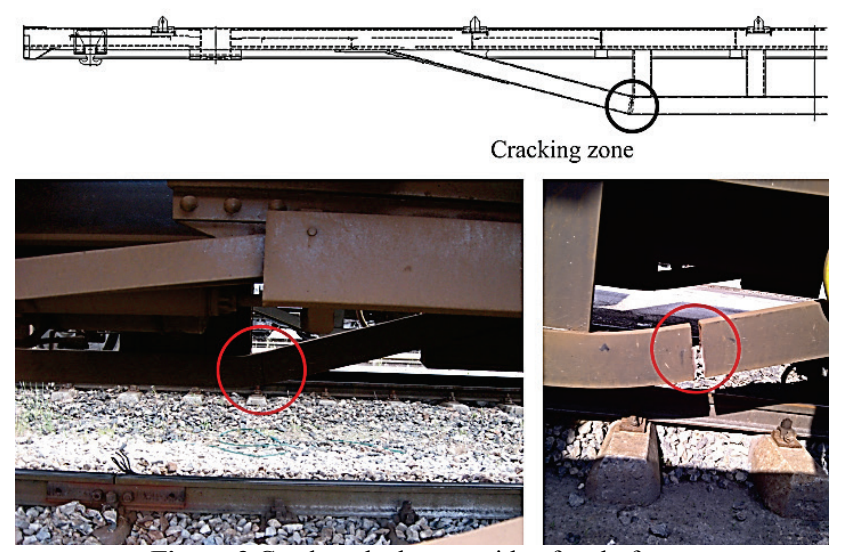

Figure 3 Crack at the bottom side of underframe

\subsection{Fatigue load case}

According to standards UIC 592-4 [12], point 1.1.1.1 and 1.1.1.2 and UIC 592-2 [13], point 2.3, all vertical load cases (vertical load from SB and vertical load from containers) are analyzed. For the analysis of fatigue load case the most unfavorable load case (vertical load from swap bodies - 2xSB - Group 20, 21, mass 31t) was used. Fatigue load case, acceleration in $\mathrm{Z}$ direction, is specified by TSI standard [5], Clause 4.2.2.3.3 and British Standard (BS EN 12663:2000) [14], Clause 4.6, 5.2, Table 16. Limit values for static test to verify fatigue strength, determined for minimum number of two million constant amplitude cycles, using Eurocode 3 [15]. For the most conventional wagon designs, the loading defined in Table 16 of British Standard (BS EN 12663:2000) [14] is considered as sufficient to represent the full effective combination of fatigue load cycles. Source of fatigue loading is determined according to TSI standard, Annex $\mathrm{CC}$ [5]. The dynamic load used in design is in range of $\pm 30 \%$ of vertical static load. According to this load case, numerical calculated stresses were used for fatigue failure analysis of the most critical zones based on S-N approach.

\subsection{Numerical analysis of the wagon structure}

The wagon is modelled using the Femap software [16]. Analysis was performed using the finite element software package PAK [10]. According to the structure type, rectangular and triangular (four and three nodes respectively) shell elements of the appropriate thickness and 3D eight node elements (for modelling of support plate, compensating ring, traction stop) are used for creating the finite element mesh. The structure is modelled in details with 54735 elements ( 88 triangular shell elements, 54647 rectangular shell elements) and 56620 nodes. Significant loaded zones are modelled without triangular shell elements. The element length is approximately $40 \mathrm{~mm}$. Different thicknesses of shell elements are presented with different colours. The model of wagon without the bogies is presented in Fig. 4. At the place of coupling bogie and compensating ring, boundary conditions were used to simulate the behaviour of the spherical joint.

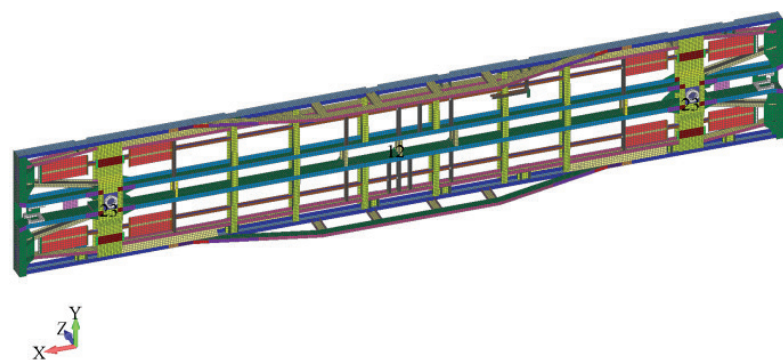

Figure 4 Finite element model of wagon

For load cases linear static analysis was performed. Structural steels S235JRG2 (with $235 \mathrm{MPa}$ and $360 \mathrm{MPa}$ as yield limit and failure limit) and $\mathrm{S} 355 \mathrm{~J} 2+\mathrm{N}$ (with 355 $\mathrm{MPa}$ and $470 \mathrm{MPa}$ as yield limit and failure limit) are used for all structural elements. Both types of steel have the same elastic material properties $\left(2,1 \times 10^{5} \mathrm{MPa}\right.$, $7,85 \times 10^{-6} \mathrm{~kg} / \mathrm{mm}^{3}$ and 0,3 as Young Modulus, density and Poisson ratio).

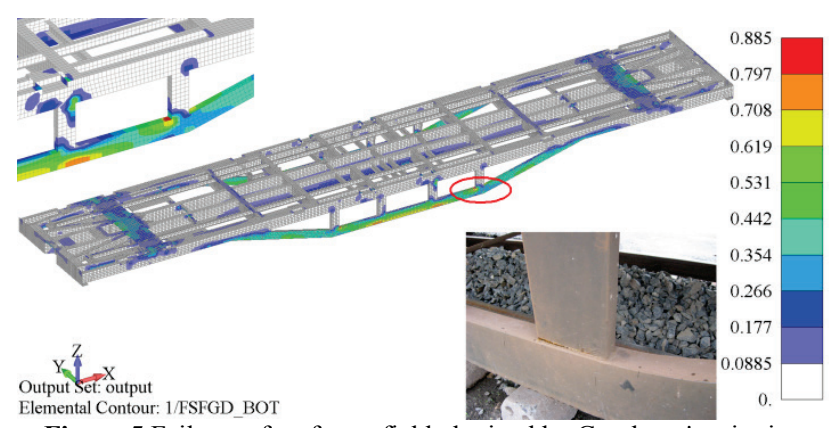

Figure 5 Failure safety factor field obtained by Goodman's criterion (principal stresses)

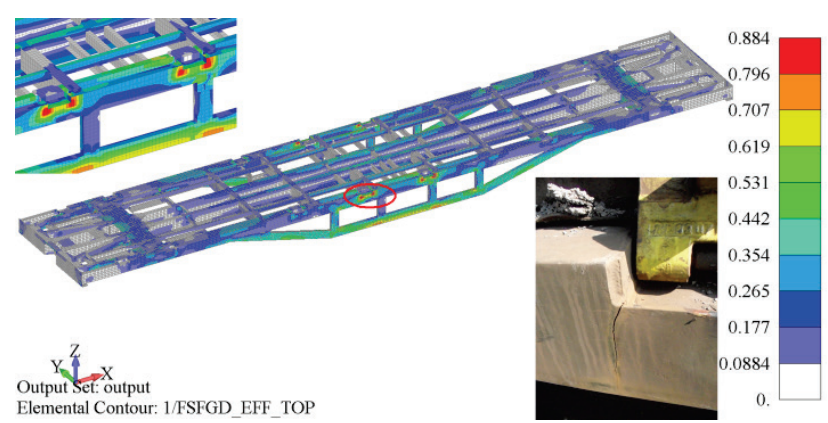

Figure 6 Failure safety factor field obtained by fatigue criterion based on the equivalent stress range 
Fields of reciprocal value of failure safety factor obtained by Goodman's criterion and fatigue criterion based on the equivalent stress range are presented in Fig. 5 and Fig. 6 respectively. Fig. 5 and Fig. 6 show the fields of reciprocal value of failure safety factor for the fatigue strengths at 2 million cycles, for the case the whole wagon is made of the parent material.

Wagons are welded constructions and to clearly define the critical zones all welded joints must be analyzed separately. According to Eurocode 3 and technology of welding it is necessary to determine category type of welds, and then to assess the integrity of the observed part of the construction. With the previously displayed figures, we can clearly see critical zones with cracks, with small values of fatigue safety factor.

In order to make the best observed structural assessment of the failure safety factor, it is necessary to define every welded joint of wagon and observe each individually.

The cracks on eighty percent of all wagons appeared on the bottom side of underframe nearby the welded joint. Because of this fact, welded joint of two plates which close rolled steel profile of bottom side of underframe was considered, Fig. 7.

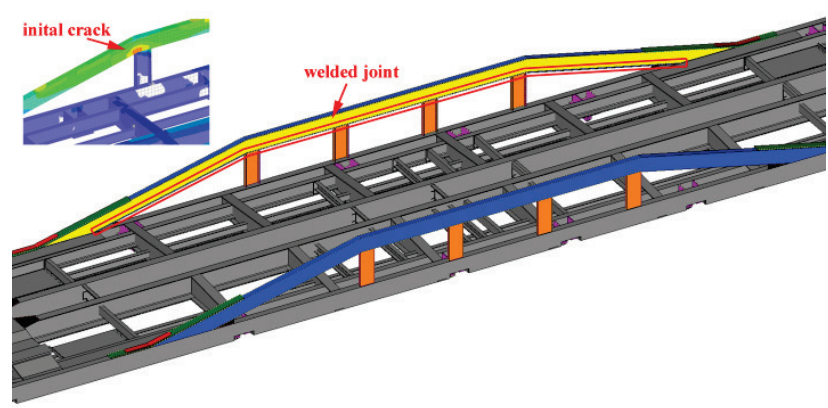

Figure 7 Welded joint which close rolled steel profile of bottom side of underframe and crack location

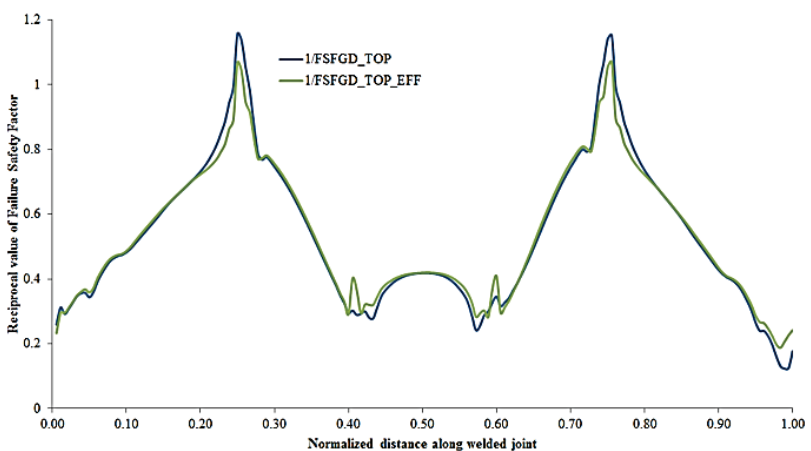

Figure 8 Distribution of reciprocal value of failure safety factor along welded joint.

A review of weld types in accordance with the Eurocode-3, Section 1.9 and based on the documentation on the technology of welding showed that the observed type of welded joint belongs to the category 71 type of welds. This type of weld is given in the Eurocode-3, Section 1.9 in Table 8.3, constructional detail 13 (butt welds made from one side only) [15]. In accordance with these facts, at the place of mentioned welded joint, calculated failure safety factor is scaled and diagram of reciprocal value of failure safety factor versus normalized distance along welded joint is given in Fig. 8.
According to calculation results at the place of weld, Fig. 8, reciprocal value of failure safety factor for the fatigue strengths at 2 million cycles is higher than 1 for the Goodman's criterion and fatigue criterion based on the equivalent stress range. On the basis of these facts, it can be concluded that the observed cracks (Fig 9) [11] on wagon type Sgmns are caused by service (fatigue) load.

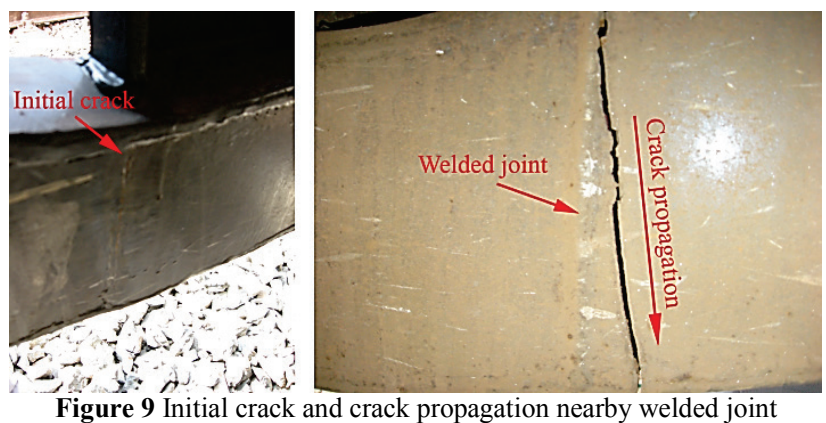

\section{Conclusion}

The paper presents the S-N approach to fatigue failure analysis of welded joints of wagon structure. The wagon structure used for this study is Sgmns wagon designed for the transportation of containers and Swap Bodies (SBs) within block trains. Numerical analysis of the wagon structure for the fatigue load case, according to standards, is done. The results obtained by FEM analysis are used for criteria of failure.

Goodman's criterion and fatigue criterion based on the equivalent stress range, implemented in the software package PAK, were used for the analysis of the fatigue failure. Calculation of fatigue safety factor was determined to assess the integrity of wagon structure parts according to the most commonly used European standards for wagon analysis. According to failure safety factors obtained by Goodman's criterion and fatigue criterion based on the equivalent stress range it should be noticed that both methods give good results. Both criteria give us adequate identification causes of cracking on the underframe of wagon for containers transportation. The results and their well matching prove reliability of both fatigue failure criteria as well as that they can be used for integrity assessment of wagon structure parts.

\section{Acknowledgements}

The part of this research is supported with the Project TR32036 "The development of the software for solving coupled multi-physical problems" financed by the Ministry of Education, Science and Technological Development, Republic of Serbia.

\section{References}

[1] Jovičić, G.; Živković, M.; Vulović, S. Proračunska mehanika loma i zamora, Monografija, Fakultet Inženjerskih nauka Kragujevac, 2011.

[2] Lassen, T.; Recho, N. Fatigue Life Analyses of Welded Structures, Great Britain and United States. ISTE Ltd., 2006. DOI: $10.1002 / 9780470612149$ 
[3] Hertzberg, R. W. Deformation and Fracture Mechanics and Engineering Materials. John Wiley and Sons, Hoboken, NJ: 1996.

[4] Juvinall, R. C.; Marshek, K. M. Fundamentals of Machine Component Design, second ed., John Wiley \& Sons, 1991.

[5] TSI standard. Commission decision of 28 July 2006 concerning the technical specification of interoperability relating to the subsystem rolling stock $G$ freight wagons of the trans-European conventional rail system (notified under document number C(2006) 3345); 2006.

[6] Ritchie, R. O. Mechanisms of fatigue-crack propagation in ductile and brittle solids. // International Journal of Fracture. 100, 1(1999), pp. 55-83. DOl: 10.1023/A:1018655917051

[7] Hussain, K. Short Fatigue Crack behavior and Analytical Models: A Review. // Engineering Fracture Mechanics. 58 4(1997), pp. 327-354. DOI: 10.1016/S0013-7944(97)00102-1

[8] Stephens, R.; Fatemi, A.; Stephens, R.; Fuchs, H. Metal Fatigue in Engineering, New York: John Wiley \& Sons Inc., 2001.

[9] Bannatine, J.; Comer, J.; Handrock, J. Fundamentals of Metal Fatigue Analysis, New Yersey: Prentice Hall, 1990.

[10] Živković, M.; Kojić, M.; Slavković, R.; Grujović, N. PAK$S$ program for FEM structural analysis. Serbia: Faculty of Me-chanical Engineering, University of Kragujevac; 2003.

[11] Milovanović, V.; Dunić, V.; Rakić, D.; Živković, M. Identification causes of cracking on the underframe of wagon for containers transportation - Fatigue strength assessment of wagon welded joints. // Engineering Failure Analysis. 31, (2013), pp. 118-131. DOl: 10.1016/j.engfailanal.2013.01.039

[12] International standard. UIC Code 592-4: swap bodies for grab handling and spreader gripping - technical conditions; 2007.

[13] International standard. UIC Code 592-2: large containers for transport on wagons - technical conditions to be fulfilled by large containers accepted for use in international, traffic; 2007.

[14] British Standard. Railway applications G structural requirements of railway vehicle bodies. BS EN 12663:2000.

[15] European standard. Eurocode 3: design of steel structures Part 1.9: Fatigue. prEN 1993-1-9:2003.

[16] FEMAP, version 10 user guide. Munich, Germany: Siemens Product Lifecycle Management Software Inc; 2009.

\section{Authors' addresses}

Vladimir Milovanović

University of Kragujevac, Faculty of Engineering,

Sestre Janjić 6, 34000 Kragujevac, Serbia

E-mail: vladicka@kg.ac.rs

\section{Miroslav Živković}

University of Kragujevac, Faculty of Engineering, Sestre Janjić 6, 34000 Kragujevac, Serbia

E-mail: zile@kg.ac.rs

\section{Gordana Jovičić}

University of Kragujevac, Faculty of Engineering,

Sestre Janjić 6, 34000 Kragujevac, Serbia

E-mail: gjovicic.kg.ac.rs@gmail.com

\section{Dražan Kozak}

Mechanical Engineering Faculty in Slavonski Brod,

Josip Juraj Strossmayer University of Osijek,

Trg Ivane Brlić-Mažuranić 2, 35000 Slavonski Brod, Croatia

E-mail:dkozak@sfsb.hr 